\title{
Use of parasites as biological tags in stock identification of the black scabbardfish, Aphanopus carbo Lowe, 1839 (Osteichthyes: Trichiuridae) from Portuguese waters
}

\author{
MARIA JOÃO SANTOS, AURÉLIA SARAIVA, CRISTINA CRUZ, JORGE C. EIRAS, \\ MARGARIDA HERMIDA, CARLA VENTURA and JOÃO PAULO SOARES \\ Departamento de Zoologia e Antropologia, Faculdade de Ciências, Universidade do Porto, Rua do Campo Alegre, s/n, \\ FC4, 4169-007 Porto, Portugal. E-mail: mjsantos@fc.up.pt \\ CIIMAR, Centro Interdisciplinar de Investigação Marinha e Ambiental, Universidade do Porto, Rua dos Bragas 289, \\ 4050-123 Porto, Portugal.
}

\begin{abstract}
SUMMARY: We studied the use of parasites as biological tags for discriminating fish stocks of Aphanopus carbo (Osteichthyes: Trichiuridae) from Portugal (Sesimbra on the mainland, Madeira and the Azores). Sixteen different metazoan parasites were found (14 from Madeira, 9 from Sesimbra and 7 from the Azores). Some parasites occurred only in fish from Madeira. The prevalence and mean intensity of the infection was recorded for each parasite and locality, and their values were statistically compared between the three sampling localities and related to host length classes. The differences between some of these parameters were statistically significant among the three localities or between two of them. It is suggested that 6 parasites (Tentacularia coryphaenae, Sphyriocephalus tergestinus, Campbelliella heteropoeciloacantha, Anisakis spp., Bolbosoma vasculosum and unidentified Acanthocephala larvae) can be used as biological tags to discriminate Portuguese stocks of Aphanopus carbo.
\end{abstract}

Keywords: parasites, biological tags, Aphanopus carbo, fish, Portugal.

RESUMEN: USO DE PARÁSITOS COMO MARCADORES BIOLÓGICOS EN LA IDENTIFICACIÓN DE STOCKS DE SABLE NEGRO, APHANOPUS CARBo Lowe, I839 (Osteichthyes: TrichiURidAe) EN AgUaS PORTUGUeSAS. - Se estudió el uso de parásitos como marcadores biológicos para discriminar los stocks de Aphanopus carbo (Osteichthyes, Trichiuridae) de Portugal (Sesimbra en el continente, Madeira y Azores Islas). Dieciséis parásitos metazoarios fueron encontrados (14 en Madeira, 9 en Sesimbra y 7 en Azores). Algunos parásitos se presentaron sólo en Madeira. La prevalencia y la intensidad media de las infecciones fueron calculadas para cada parásito y cada región, y sus valores fueron comparados estadísticamente entre los tres lugares de muestreo, y relacionados con la talla del huésped. Se encontraron diferencias estadísticamente significativas entre algunos de estos parámetros de las tres regiones o entre dos de ellas. Se sugiere que 6 parásitos (Tentacularia coryphaenae, Sphyriocephalus tergestinus, Campbelliella heteropoeciloacantha, Anisakis spp., Bolbosoma vasculosum y larvas no identificadas de Acanthocephala) pueden ser usados como marcadores biológicos para discriminación de stocks de Aphanopus carbo de Portugal.

Palabras clave: parásitos, marcadores biológicos, Aphanopus carbo, peces, Portugal.

\section{INTRODUCTION}

Fish stock discrimination is particularly important for economically valuable species. In fact, it may help to establish the fishing periods and catch- ing efforts appropriate to a particular fishing ground, with a view to identifying measures to sustain or increase fisheries.

The black scabbardfish, Aphanopus carbo Lowe, 1839 (Osteicthyes: Trichiuridae) is an economi- 
cally important deep-sea fish species that has been exploited in the eastern Atlantic, off the Madeira Islands, for several decades. About 30 years ago, this species was also reported near Sesimbra, on the west coast of mainland Portugal, and off the Azores Islands. Since then, the Sesimbra population has undergone intense fishing, whereas at the Azores the captures have been much lower, and the fishery activity is therefore irregular.

Studies on the biology of black scabbardfish, mainly from Portuguese populations, include parasite (Costa et al., 1996, 2000, 2003a, b; Pontes et al., 2005; Cruz et al., 2009), distribution (Parin, 1986), fisheries (Leite, 1989; Martins and Ferreira, 1995; Gordon, 2001), age and growth (Williams and Bedford, 1974; Morales-Nin and Sena-Carvalho, 1996; Morales-Nin et al., 2002) and reproduction (Figueiredo et al., 2003). The proposal for the existence of more than one stock among these populations of black scabbardfish in Portuguese waters has already been discussed using fish genetic analysis of mitochondrial DNA variation of part of the cytochrome $b$ gene. Quinta et al. (2004) suggested that populations from mainland Portugal and the Madeira Islands belong to two different stocks. Stephani and Knutsen (2007) refuted this analysis and suggested the discrimination of two phylogroups, one for the Azores and one for the mid-Atlantic Ridge (the Faraday seamount), Madeira and mainland Portugal. However, in spite of these studies, the existence of a possible relationship between the fish populations from the three areas (Sesimbra, Madeira and Azores) is not fully known.

A number of studies has shown that parasites may be used as biological tags in the discrimination of fish stocks from different geographical localities (Marcogliese et al., 2003; Oliva et al., 2004; Marques et al., 2005; Melendy et al., 2005; McClelland and Melendy, 2007; Mackenzie et al., 2008; Ferreira Marques et al., 2009). Review articles on this subject, including the procedures and methods employed in the use of parasites as biological tags, may be found in MacKenzie and Abaunza (1998; 2005), Mosquera et al. (2000), MacKenzie (2002, 2004), Timi (2007), Abaunza et al. (2008) and Lester and MacKenzie (2009). The ideal tag parasite is a parasite that has significantly different levels of infection among localities which persist for a long period (a permanent parasite), that is easily detected and identified, and that does not cause serious damage to the host (MacKenzie and Abaunza, 1998, 2005).
The objective of the present study was therefore to identify the parasites of $A$. carbo that can be used as biological tags to discriminate fish stocks from the three different localities.

\section{MATERIALS AND METHODS}

From Autumn 2005 to Summer 2006, a total of 289 specimens of $A$. carbo captured by artisanal longline fishery were sampled at landing (Fig. 1): 116 specimens from Sesimbra $\left(38^{\circ} 15^{\prime} \mathrm{N} ; 9^{\circ} 10^{\prime} \mathrm{W}\right)$ (30 in Autumn, 30 in Winter, 29 in Spring and 27 in Summer), 120 specimens from Madeira ( $32^{\circ} 36^{\prime} \mathrm{N}$; $\left.16^{\circ} 54^{\prime} \mathrm{W}\right)$ ( 30 in each season), and 53 specimens from the Azores $\left(38^{\circ} 24^{\prime} \mathrm{N} ; 28^{\circ} 15^{\prime} \mathrm{W}\right)(28$ in Autumn and 25 in Spring). The samples were performed seasonally to get a broad knowledge of the black
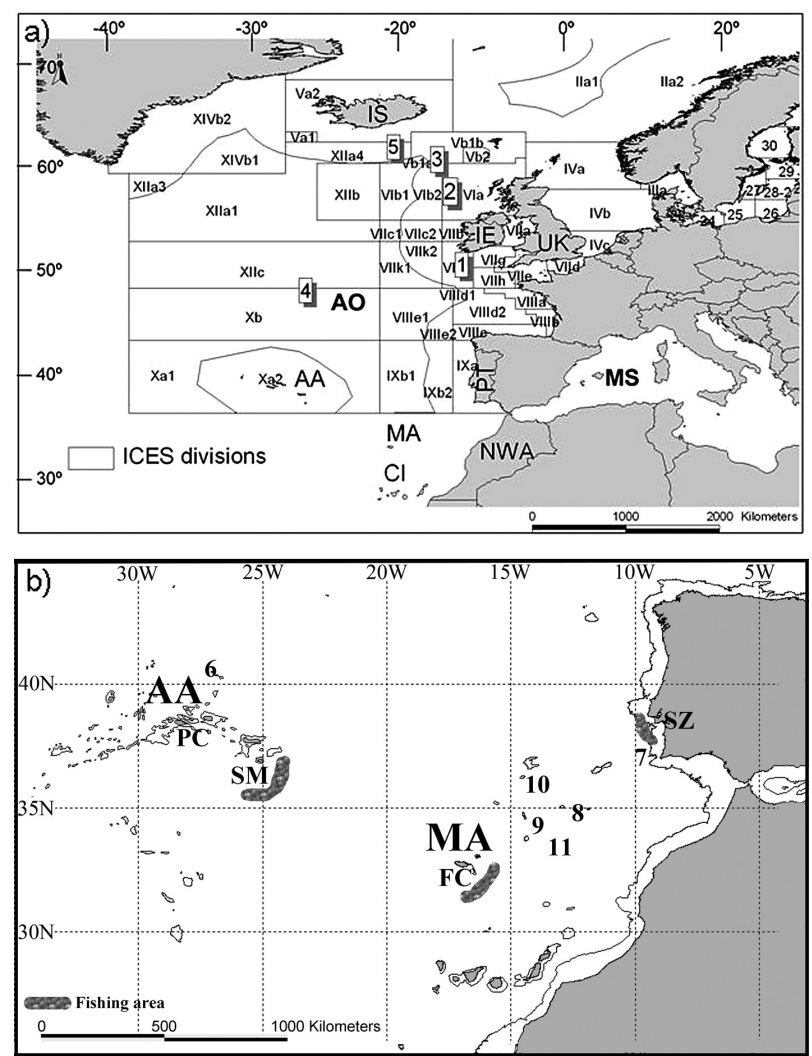

FIG. 1. - a) Map of the northeast Atlantic with the ICES divisions and $b$ ) the southern northeast Atlantic with the sampling locations of black scabbardfish and the $1000 \mathrm{~m}$ isobath. AA, Azores Archipelago; AO, Atlantic Ocean; CI, Canary Islands; FC, Funchal; IE, Ireland; IS, Iceland, MA, Madeira Archipelago; MS, Mediterranean Sea; NWA, Northwest Africa; PC, Pico Island; PT, mainland Portugal; SM, Santa Maria Island; SZ, Sesimbra (mainland Portugal); UK, United Kingdom; 1, Porcupine Seabight; 2, Rockall Trough; 3, Hatton Bank; 4, Faraday seamount; 5, Reykjanes Ridge; 6, Sedlo seamount; 7, Gorringe seamount; 8 , Ampère seamount; 9 , Unicorn bank; 10, Lion seamount; 11 , Seine seamount. 
scabbardfish parasitofauna, once it is known that some parasite species may exhibit seasonality and thus occur only at a particular time of the year.

To assure that only Aphanopus carbo was sampled, an effort has been made to verify if specimens from A. intermedius were present in the samples and every individual morphologically analysed belonged to A. carbo. All the specimens were kept individually in plastic bags and frozen for later examination. Each specimen was measured, weighed, sexed and thoroughly examined for detection of metazoan parasites. The parasitological survey was done with the aid of a stereomicroscope (20x) and a microscope (400x) and included the examination of several organs: integument, gills, digestive tract, liver, spleen, gall bladder, swimbladder, gonads and muscle. All the parasites were collected and preserved in $70 \%$ ethanol for subsequent identification.

Parasite identification was performed by morphological analysis to the lowest taxonomic level possible, depending on the preservation stage of each parasite. For the identification of Anisakis larvae, a detailed morphological analysis recorded two types of Anisakis larvae (type I and type II) that are generally associated with two different groups of species. Hence, we can assume that at least two species are present in our samples. In this genus, due to the lack of more morphological features present in the larvae, only its molecular study would be able to provide an accurate identification to the species level. However, since this was not considered essential to the identification of parasite tags, it was considered to be beyond the scope of the present work.

The prevalence (percentage of infected hosts on observed hosts) and mean intensity (mean number of parasites of the infected hosts) were calculated for each parasite taxon at the three sampling localities (except for Ceratomyxa sp., for which only the prevalence was calculated because the exact number of spores detected is not easily determined) (Bush et al., 1997).

In order to compare the parasite parameters among the three localities, several non-parametrical statistical analyses were performed for the parasite taxa that fulfilled the minimum features required for a parasite tag. The occurrence of parasites was analysed between pairs of localities by the chi-square test or the Fisher's test, while the comparisons of intensity of infection between pairs of localities were conducted with the Mann-Whitney's U-test.
TABLE 1. - Black scabbardfish (Aphanopus carbo) distribution for each fork length class.

\begin{tabular}{lcccc}
\hline Length classes & Sesimbra & $\begin{array}{c}\text { Localities } \\
\text { Madeira }\end{array}$ & Azores & Total \\
\hline Class 1 $(<90 \mathrm{~cm})$ & 22 & 0 & 0 & 22 \\
Class 2 $(90-99.9 \mathrm{~cm})$ & 29 & 6 & 8 & 43 \\
Class 3 $(100-109.9 \mathrm{~cm})$ & 51 & 38 & 26 & 115 \\
Class 4 $(110-119.9 \mathrm{~cm})$ & 14 & 67 & 16 & 97 \\
Class 5 $(>120 \mathrm{~cm})$ & 0 & 9 & 3 & 12 \\
$\mathrm{n}$ & 116 & 120 & 53 & 289 \\
& & & & \\
\hline
\end{tabular}

Appropriate host features were also studied as these might influence the distribution of the infections among the examined fish. Sex, fork length and total weight of the host were therefore analysed. The sex ratio, i.e. the proportion of males to females, was analysed for pairs of localities by a chi-square test, while the fork length and total weight of the fish specimens were compared between pairs of localities through the Mann-Whitney's U-test.

Taking into account the total range of fish lengths found in the observed samples, and a minimum number of fish per class (Table 1), five length classes (fork length) were considered: $\mathrm{Cl} 1,<90.0 \mathrm{~cm} ; \mathrm{Cl} 2$, 90.0-99.9 cm; Cl3, 100.0-109.9 cm; Cl4, 110.0-119.9 $\mathrm{cm}$, and $\mathrm{Cl} 5, \geq 120 \mathrm{~cm}$. However, the analysis was restricted to the classes of which fish were found at all three geographical localities: $\mathrm{Cl} 2, \mathrm{Cl} 3$ and $\mathrm{Cl} 4$. Since infection levels may be related to host size, we further compared the most important taxa, B. vasculosum, in terms of occurrence and intensity and Anisakis spp. in terms of intensity, given the same length class, between the pair of sampling localities.

The results were expressed as "significant" $(\mathrm{P}<0.05)$, and "not significant" $(\mathrm{P} \geq 0.05)$. Alternatively, they were expressed as "not analyzed" when data did not fulfil the conditions for performing the analysis, or as "not determined", either because the taxa were excluded from the set of potential biological tags when they failed to fulfil the minimum criteria, or because they were only found at a single locality. All statistical tests were performed using SPSS version 16.0 for Windows (SPSS Inc., 2007).

\section{RESULTS}

Host sex and fork length and total weight average values are shown in Table 2 for each of the localities and for the whole sampled fish. Sexes were evenly distributed in the three localities but fish size showed 
TABLE 2. - Fork length (cm), total weight (g), and sex ratio of Aphanopus carbo, and statistical significance between the values recorded for the three sampling localities (Ses, Sesimbra; Mad, Madeira; Azo, Azores) assessed by Mann-Whitney's U (MW) and chi-square ( $\left.\chi^{2}\right)$ tests $($ s.d. $=$ standard deviation, $\min .=$ minimum, $\max .=$ maximum $)$.

\begin{tabular}{|c|c|c|c|c|c|}
\hline & Sesimbra & Madeira & Azores & Total & $\begin{array}{l}\text { Sampling localities with } \\
\text { significant difference values (p) }\end{array}$ \\
\hline $\begin{array}{l}\text { Fork length } \\
\text { mean } \pm \text { s.d. } \\
(\min -\max ) \\
n\end{array}$ & $\begin{array}{c}98.9 \pm 9.5 \\
(70-117) \\
116\end{array}$ & $\begin{array}{c}111.0 \pm 6.3 \\
(93-126) \\
120\end{array}$ & $\begin{array}{c}107.0 \pm 7.1 \\
(92-121) \\
53\end{array}$ & $\begin{array}{c}105.4 \pm 9.6 \\
(70-126) \\
289\end{array}$ & $\begin{array}{c}\text { MW } \\
\text { Ses-Mad }(0.000) \\
\text { Mad-Azo }(0.000) \\
\text { Ses-Azo }(0.000)\end{array}$ \\
\hline $\begin{array}{l}\text { Total weight } \\
\text { mean } \pm \text { s.d. } \\
(\min -\max ) \\
\text { n }\end{array}$ & $\begin{array}{c}1540.9 \pm 491.0 \\
(483-2743) \\
116\end{array}$ & $\begin{array}{c}2096.8 \pm 387.1 \\
(1042-3018) \\
120\end{array}$ & $\begin{array}{c}1819.0 \pm 344.8 \\
(1266-2736) \\
53\end{array}$ & $\begin{array}{c}1822.7 \pm 492.9 \\
(483-3018) \\
289\end{array}$ & $\begin{array}{c}\text { MW } \\
\text { Ses-Mad }(0.000) \\
\text { Mad-Azo }(0.000) \\
\text { Ses-Azo }(0.000)\end{array}$ \\
\hline $\begin{array}{l}\text { Sex }(\%) \\
\text { Males } \\
\text { Females } \\
n\end{array}$ & $\begin{array}{l}47.1 \\
52.9 \\
102\end{array}$ & $\begin{array}{c}50.0 \\
50.0 \\
118\end{array}$ & $\begin{array}{c}35.8 \\
64.2 \\
53\end{array}$ & $\begin{array}{l}46.2 \\
53.8 \\
273\end{array}$ & $\begin{array}{c}\chi^{2} \\
\text { Not significant }\end{array}$ \\
\hline
\end{tabular}

TABLE 3. - Parasites detected in Aphanopus carbo in the three sampling localities. Abbreviations: +, present; dt, digestive tract; g, gills; gb, gall bladder; go, gonads; l, liver; s, spleen; sb, swimbladder.

\begin{tabular}{|c|c|c|c|c|}
\hline Parasites & $\begin{array}{l}\text { Infection } \\
\text { site }\end{array}$ & Sesimbra & $\begin{array}{c}\text { Localities } \\
\text { Madeira }\end{array}$ & Azores \\
\hline \multicolumn{5}{|l|}{ Myxozoa } \\
\hline $\begin{array}{l}\text { Ceratomyxa sp. } \\
\text { Monogenea }\end{array}$ & $\mathrm{gb}$ & + & + & + \\
\hline Octoplectanocotyla aphanopi & $\mathrm{g}$ & + & + & \\
\hline \multicolumn{5}{|l|}{ 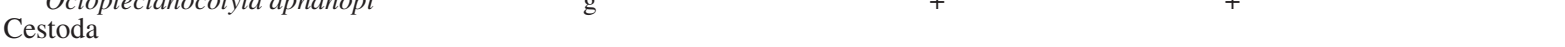 } \\
\hline \multicolumn{4}{|l|}{ Trypanoryncha larvae } & + \\
\hline Tentacularia coryphaenae & $\mathrm{dt}$ & & + & \\
\hline Sphyriocephalus tergestinus & $\mathrm{dt}$ & + & + & \\
\hline Nybelinia lingualis & $\mathrm{dt}$ & & + & + \\
\hline Nybelinia thyrsites & $\mathrm{dt}$ & & + & \\
\hline Heteronybelinia yamagutii & $\mathrm{dt}$ & + & + & + \\
\hline Heteronybelinia sp. & $\mathrm{dt}$ & & + & \\
\hline Campbelliella heteropoeciloacantha & $\mathrm{dt}$ & & + & \\
\hline \multicolumn{5}{|l|}{ Digenea } \\
\hline Lecithochirium musculus & $\mathrm{dt}$ & & & + \\
\hline \multicolumn{5}{|l|}{ Nematoda } \\
\hline Anisakis spp. & $\mathrm{dt}, 1, \mathrm{~s}, \mathrm{go}, \mathrm{sb}$ & + & + & + \\
\hline Unidentified & $\mathrm{dt}$ & + & & \\
\hline \multicolumn{5}{|l|}{ Acanthocephala } \\
\hline Bolbosoma vasculosum & $\mathrm{dt}$ & + & + & + \\
\hline Unidentified larvae & $\mathrm{dt}$ & + & + & \\
\hline Unidentified adult & $\mathrm{dt}$ & & + & \\
\hline
\end{tabular}

significant differences among localities, being higher at Madeira and lower at Sesimbra.

As shown in Table 3, 16 metazoan parasites were detected in the sampled group of 289 black scabbard fish. Fish from Madeira presented the highest number of parasitic taxa (14), while those from the Azores presented the lowest (7).

According to the present data, five taxa occurred exclusively in fish from Madeira: Tentacularia coryphaenae, Nybelinia thyrsites, Heteronybelinia sp., Campbelliella heteropoeciloacantha and an unidentified Acanthocephala adult. Lecithochirium musculus was exclusive from the Azores and an unidenti- fied Nematode was exclusive from Sesimbra. The taxa Octoplectanocotyla aphanopi, Sphyriocephalus tergestinus and unidentified Acanthocephala larvae occurred off both Madeira and Sesimbra, while Nybelinia lingualis was found off Madeira and the Azores. No taxa common to only Sesimbra and the Azores were observed. Finally, Ceratomyxa sp., Tetraphylidae larvae, Heteronybelinia yamaguti, Anisakis spp. and Bolbosoma vasculosum were found at the three localities.

As an additional parasitofauna characterisation of the black scabbardfish, it can be mentioned that quite large cysts of the fungus Ichthyophonus 
TABLE 4. - Prevalence of the parasites of Aphanopus carbo and statistical significance between the values obtained at the three sampling localities (Ses, Sesimbra; Mad, Madeira; Azo, Azores) determined by chi-square test.

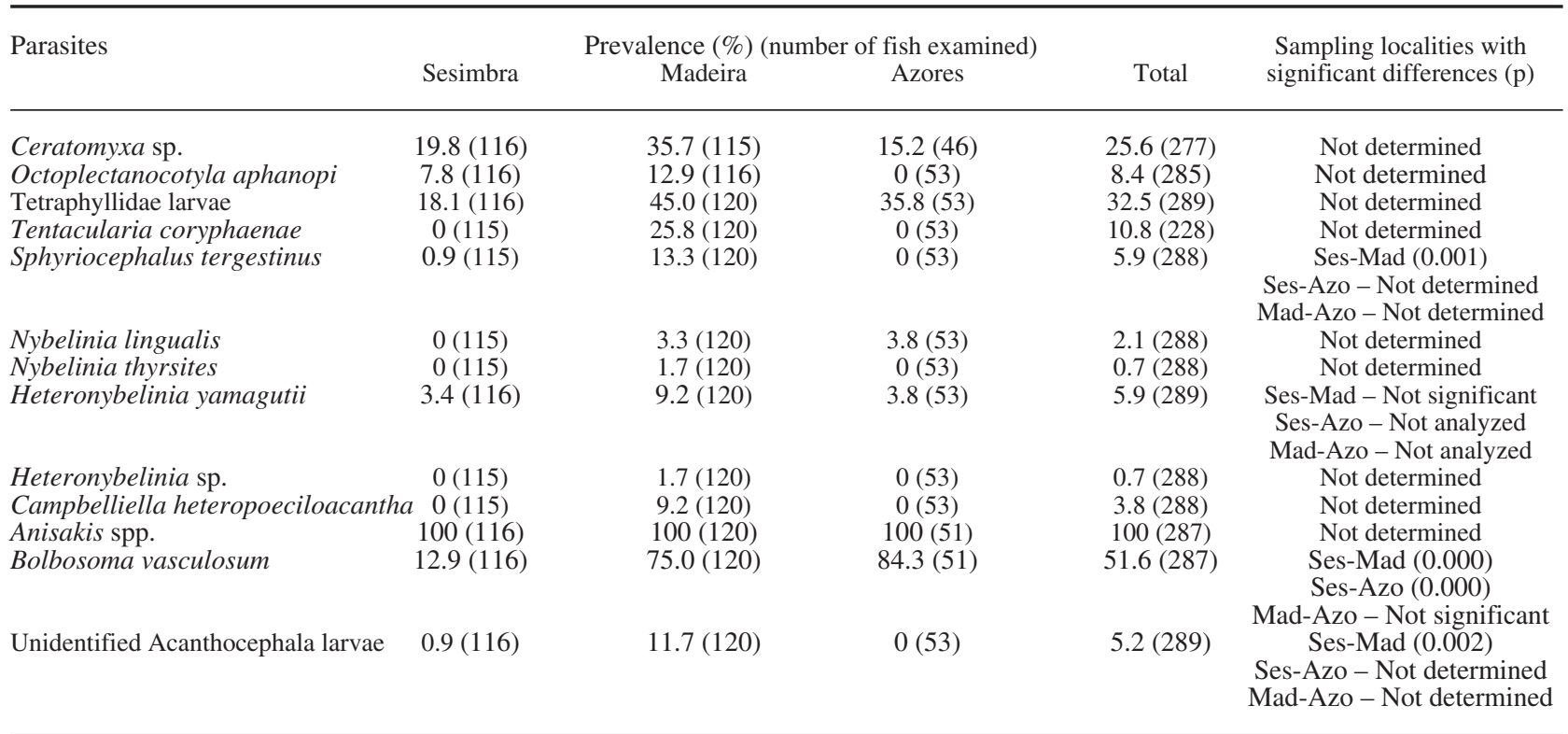

hoferi were also found in several organs, mostly in kidney, spleen and liver. The intensity of infection sometimes reached several hundreds of cysts per organ, with high values of prevalence at all localities (87.8\% off Sesimbra, $85.8 \%$ off Madeira and $66.0 \%$ off the Azores).

From the 16 metazoan taxa mentioned above, three parasites were found only once, and thus considered accidental: L. musculus was found in the stomach of a specimen from the Azores; an unidentified nematode was found in the muscle of a specimen from Sesimbra; and an unidentified adult acanthocephalan was found in the digestive tract of a fish from Madeira.

The prevalence of infection for all the 13 taxa considered as non-accidental parasites is shown in Table 4. Three of them, $N$. lingualis, $N$. thyrsites and Heteronybelinia sp., showed prevalence values lower than 5\% (rare species) at all three localities. Due to their low occurrence they were not considered useful as biological tags and thus not compared among localities.

The monogenean Octoplectanocotyla aphanopi and Tetraphyllidae larvae were rejected as possible biological tags because their life spans are probably less than one year and Ceratomyxa sp. was also rejected because its life span is unknown. Therefore, although their prevalence and mean intensity values are presented in Tables 4 and 5, they were not compared among localities.

To quantify the differences among the three localities, pairwise comparisons of infection levels were only performed for the following seven taxa, so far accepted as potential biological tags: Tentacularia coryphaenae, Sphyriocephalus tergestinus, Heteronybelinia yamagutii, Campbelliella heteropoeciloacantha, Anisakis spp., Bolbosoma vasculosum and unidentified Acanthocephala larvae.

When the analysis addressed prevalence, significant differences were found for three parasite taxa: $S$. tergestinus, B. vasculosum larvae and the unidentified Acanthocephala larvae (Table 4). The chisquare test was not applied to $T$. coryphaenae and C. heteropoeciloacantha because the parasites were only present off Madeira or to Anisakis spp. because it showed $100 \%$ prevalence for all three localities.

The highest prevalences were always observed off Madeira, with the exception of B. vasculosum, whose maximum prevalence was found off Madeira and the Azores. No significant differences among localities were reported for $H$. yamagutii (Table 4).

The mean intensity of infection for the non-occasional parasite taxa is shown in Table 5. Significant differences among the three localities were found for two parasite taxa (Anisakis spp. and B. vasculosum), whose highest values of mean intensity were observed in Madeira. No significant differences among localities were reported for $S$. tergestinus, $H$. yamagutii and unidentified Acanthocephala larvae intensity. The Mann-Whitney's U-test was not applied to $T$. coryphaenae and $C$. heteropoeciloacantha because the parasites were only present off Madeira. 
TABLE 5. - Intensity [mean (range)] of infection of Aphanopus carbo and statistical significance between the values obtained at the three sampling localities (Ses, Sesimbra; Mad, Madeira; Azo, Azores) determined by the Mann-Whitney test.

\begin{tabular}{|c|c|c|c|c|c|}
\hline \multirow[t]{3}{*}{ Parasites } & \multicolumn{4}{|c|}{ Intensity } & \multirow{3}{*}{$\begin{array}{l}\text { Sampling localities with } \\
\text { significant differences (p) }\end{array}$} \\
\hline & \multirow{2}{*}{ Sesimbra $^{\mathrm{M}}$} & \multicolumn{3}{|c|}{ Mean (minimum - maximum) (number of fish infected) } & \\
\hline & & Madeira & Azores & Total & \\
\hline Ceratomyxa sp. & - & - & - & - & \\
\hline Octoplectanocotyla aphanopi & $2.44(1-5)(9)$ & $1.47(1-4)(15)$ & (0) & $1.83(1-5)(24)$ & Not determined \\
\hline Tetraphyllidae larvae & $7.90(1-29)(21)$ & $50.24(1-714)(54)$ & $8.00(1-31)(19)$ & $32.24(1-714)(94)$ & Not determined \\
\hline Tentacularia coryphaenae & (0) & $1.77(1-6)(31)$ & (0) & $1.77(1-6)(31)$ & Not determined \\
\hline \multirow[t]{2}{*}{ Sphyriocephalus tergestinus } & $1(1)(1)$ & $1.12(1-2)(16)$ & (0) & $1.12(1-2)(17)$ & $\begin{array}{l}\text { Ses-Mad - Not significant } \\
\text { Ses-Azo - Not determined }\end{array}$ \\
\hline & & & & & Mad-Azo - Not determined \\
\hline Nybelinia lingualis & (0) & $2.00(1-5)(4)$ & $2.00(1-3)(2)$ & $2.00(1-5)(6)$ & Not determined \\
\hline Nybelinia thyrsites & (0) & $2.00(1-3)(2)$ & (0) & $2.00(1-3)(2)$ & Not determined \\
\hline Heteronybelinia yamagutii & $2.75(1-5)(4)$ & $1.64(1-3)(11)$ & $6.50(1-12)(2)$ & $2.47(1-12)(17)$ & Not significant \\
\hline Heteronybelinia sp. & (0) & $1.00(1)(2)$ & (0) & $1.00(1)(2)$ & Not determined \\
\hline Campbelliella heteropoeciloacanth & $(0)$ & $1.36(1-3)(11)$ & $(0)$ & $1.36(1-3)(11)$ & Not determined \\
\hline \multirow[t]{3}{*}{ Anisakis spp. } & 154.15 & 253.89 & 53.67 & 178.00 & Ses-Mad $(0.000)$ \\
\hline & $(12-1904)$ & $(13-1128)$ & $(13-144)$ & $(12-1904)$ & Mad-Azo (0.000) \\
\hline & (116) & $(120)$ & (51) & $(287)$ & Ses-Azo $(0.000)$ \\
\hline \multirow[t]{2}{*}{ Bolbosoma vasculosum } & $1.33(1-4)(15)$ & $5.99(1-50)(90)$ & $2.65(1-8)(43)$ & $4.55(1-50)(148)$ & Ses-Mad (0.000) \\
\hline & & & & & $\begin{array}{l}\text { Mad-Azo }(0.000) \\
\text { Ses-Azo }(0.000)\end{array}$ \\
\hline \multirow[t]{3}{*}{ Unidentified Acanthocephala larvae } & $1.00(1)(1)$ & $3.07(1-10)(14)$ & $(0)$ & $2.93(1-10)(15)$ & Ses-Mad - Not significant \\
\hline & 1.00 (1) (1) & $3.07(1-10)(14)$ & (D) & $2.85(1-10)(10)$ & Ses-Azo - Not determined \\
\hline & & & & & Mad-Azo - Not determined \\
\hline
\end{tabular}

Regarding differences on mean intensity between localities within the same length class, the taxa Anisakis spp. and B. vasculosum showed the same trend in almost all the host length classes (results not shown), i.e. higher mean values for Madeira specimens. However, prevalence of B. vasculosum was higher in the Azores.

For $H$. yamagutii no significant differences were observed in infection levels in pairwise comparisons among localities for either prevalence or mean intensity. Thus, this species did not fulfil the requirements to be used as a biological tag.

\section{DISCUSSION}

Parasite tags are more appropriate to stock identification of deepwater species than artificial tags, which on most occasions cannot be used (MacKenzie and Abaunza, 2005). Therefore, a survey of the black scabbardfish parasitofauna sampled at three different localities (Sesimbra, Madeira and Azores) was performed, to select a group of metazoan parasites to be used as biological tags for this economically valuable deepwater marine fish.

This survey revealed 4 new host records of Trypanorhyncha (Nybelinia thyrsites, Heteronybelinia yamagutii, Heteronybelinia sp. Campbelliela heteropoeciloacantha), complementing the extensive work already done by Costa et al. (1996, 2000, 2003a, b) and Pontes et al. (2005) in this fish species from Madeira Island. Also, a new geographic record is presented for the monogenean Octoplectanocotyle aphanopi, up to now reported only once for northern Europe, in Scottish waters (Pascoe, 1987), whose detailed life cycle is unknown.

From the 16 taxa recorded in this survey, only six were retained to be used as biological tags: three trypanorhynchan larvae, Tentacularia coryphaenae, Sphyriocephalus tergestinus and Campbelliella heteropoeciloacantha; one nematode, Anisakis spp.; and two acanthocephalans, Bolbosoma vasculosum and unidentified acanthocephalan larvae. The remaining taxa were excluded because they did not fulfil some of the criteria for a good biological tag (according to MacKenzie and Abaunza, 1998, 2005). Some of them (the monogenean O. aphanopi and the tetraphyllidean larvae) showed short life spans in the host (Wardle and McLeod, 1952; Whittington and Chisholm, 2008), another had an unknown life cycle (the myxozoan, Ceratomyxa sp.), others occurred occasionally or showed a very low prevalence $(L$. musculus, an unidentified nematode, an unidentified adult acanthocephalan, $N$. lingualis, $N$. thyrsites, Heteronybelinia sp.), and one did not show significantly different infection levels among localities $(H$. yamagutii).

To select the parasites of $A$. carbo that can be used as biological tags to discriminate fish stocks from the three different localities, we first adopted 
a qualitative analysis of taxa distribution, comparing the presence/absence of parasites of each of the three observed black scabbardfish populations. This qualitative discrimination was then followed by a detailed quantitative evaluation of their prevalence and intensity of infection.

The qualitative analysis of presence/absence of some taxa, showed that we can attribute an origin for a group of fishes sampled at one of the three studied localities: the presence of $T$. coryphaena and/or $C$. heteropoeciloacantha in a sample of black scabbardfish suggests that they belong to Madeira, since these species are exclusively present at this locality; the detection of S. tergestinum and/or unidentified Acanthocephala larvae, and the absence of $T$. coryphaena and $C$. heteropoeciloacantha, suggests that they belong to Sesimbra; and finally, the absence of those 4 taxa suggests that the fishes belong to the Azores.

Pairwise comparisons of the infection levels (prevalence and mean intensity) of all the 4 parasite taxa found at more than one locality revealed that, although $S$. tergestinus and an unidentified acanthocephalan larva are present off both Sesimbra and Madeira, these two localities can still be discriminated based on the prevalence of these two parasites, which were found to be significantly different. Indeed, off Sesimbra and Madeira S. tergestinus showed values of $0.9 \%$ and $13.3 \%$, respectively, and the unidentified acanthocephalan larvae values of $0.9 \%$ and $11.7 \%$, respectively.

B. vasculosum and Anisakis spp. were common to all three localities. However, they are still useful as biological tags because they show significantly different infection levels at some of the locations studied. For example, we can separate Sesimbra from the Madeira-Azores group with B. vasculosum, as its values of prevalence were $12.9 \%$ and 75.0 $84.3 \%$ at these locations, respectively. Moreover, this species had different mean intensities at all three locations: 1.33 off Sesimbra, 5.99 off Madeira and 2.65 off the Azores. Anisakis spp. can also be used to discriminate the three locations as its mean intensities are: Sesimbra - 154.15, Madeira - 253.89 and Azores - 53.67 (Cruz et al., 2009). In addition, it should be mentioned that the analyses of the prevalence and mean intensity stratified by host length for Anisakis spp. and B. vasculosum showed the same trends. This discards the potential effect of the fish size on infection levels among localities, reinforcing the attribution of these differences to the geographic distribution.
For deepwater fish there are few studies in the literature, but similar parasite taxa to those found in the present study (including Anisakids) were used to discriminate stocks of redfish, Sebastes mentella, in the northwest Atlantic between the Gulf of St. Lawrence and the Cabot Strait-Laurentian Channel in Canada (Marcogliese et al., 2003). Moreover, the use of Anisakids as biological tags is stressed by the authors, as one of the taxa that has a long life span and stable infection levels for a few years. The identification of Anisakis larvae species from the swordfish Xiphias gladius, allowed Atlantic populations to be separated from Mediterranean ones (Mattiucci et al., 2007; Mattiucci and Nascetti, 2008), the dividing line being at the western Portuguese coast.

In summary, from the 16 parasite taxa recorded for A. carbo, 6 were selected as biological tags. These discriminated the populations of the three sampled localities, leading us to the conclusion that we may be dealing with three stocks. However, in order to draw more robust conclusions about stock separation for these three localities, a multidisciplinary approach is needed, gathering information on the fish ranging from morphology (morphometrics, meristics and otolith microchemistry) to biology (life story characteristics).

\section{ACKNOWLEDGEMENTS}

This study was partially supported by Fundação para a Ciência e Tecnologia (project POCTI/ CVT/46851/2002). The authors would like to thank the anonymous reviewers for providing helpful suggestions on an earlier draft of the manuscript.

\section{REFERENCES}

Abaunza, P., A.G. Murta, N. Campbell, R. Cimmaruta, A.S. Comesaña, G. Dahle, M.T. Garcia Santamaría, L.S. Gordo, S.A. Iversen, K. MacKenzie, A. Magoulas, S. Mattiucci, J. Molloy, G. Nascetti, A.L. Pinto, R. Quinta, P. Ramos, A. Sanjuan, A.T. Santos, C. Stransky and C. Zimmermann. - 2008. Stock identity of horse mackerel (Trachurus trachurus) in the Northeast Atlantic and Mediterranean Sea: integrating the results from different stock identification approaches. Fish. Res., 89: 196-209.

Bush, A.O., K.D. Lafferty, J.M. Lotz and A.W. Shostak. - 1997. Parasitology meets ecology on its own terms: Margolis et al. revisited. J. Parasitol., 83(4): 575-583.

Costa, G., J.C. Chubb and C.J. Veltkamp. - 2000. Cystacanths of Bolbosoma vasculosum in the black scabbard fish Aphanopus carbo, oceanic horse mackerel Trachurus picturatus and common dolphin Delphinus delphis from Madeira, Portugal. J. Helminthol., 74: 113-120.

Costa, G., J.C. Eiras, J. Chubb, J. MacKenzie and B. Berland. 1996. Parasites of the black scabbard fish, Aphanopus carbo 
Lowe, 1839 from Madeira. Bull. Eur. Ass. Fish Pathol., 16: 13-16.

Costa, G.C., T. Pontes, S. Mattiucci and S. D'Amelio. - 2003a. The occurrence and infection dynamics of Anisakis larvae in the black scabbard fish, Aphanopus carbo, chub mackerel, Scomber japonicus, and oceanic horse mackerel Trachurus picturatus from Madeira, Portugal. J. Helminthol., 77: 163-166.

Costa, G.C., C.J. Veltkamp and J.C. Chubb. - 2003b. Larval trypanorhynchs (Plathyelminthes: Eucestoda: Trypanorhyncha) from black-scabbard fish, Aphanopus carbo and oceanic horse mackerel, Trachurus picturatus in Madeira (Portugal). Parasite, 10: 325-331.

Cruz, C., A. Saraiva, M. J. Santos, J. C. Eiras, C. Ventura, J. P. Soares and M. Hermida. - 2009. Parasitic infection levels by Anisakis spp. larvae (Nematoda: Anisakidae) in black scabbardfish Aphanopus carbo (Osteichthyes: Trichiuridae) from Portuguese waters. Sci. Mar., 73S2: 115-120.

Figueiredo, I., P. Bordalo-Machado, S. Reis, D. Sena-Carvalho, T. Blasdale, A. Newton and L.S. Gordo. - 2003. Observations on the reproductive cycle of the black scabbard fish (Aphanopus carbo Lowe, 1839) in the NE Atlantic. ICES J. Mar. Sci., 60: 774-779.

Gordon J.D.M. - 2001. Deepwater fisheries at the Atlantic frontier. Cont. Shelf Res., 21: 987-1003.

Leite, A.M. - 1989. The deep sea fishery of the black scabbard fish Aphanopus carbo Lowe, 1839 in Madeira island water. Proc. 1988 World Symp. Fishing Gear. Fishing Vessel Design, pp. 240-243.

Lester R.J.G. and K. MacKenzie. - 2009. The use and abuse of parasites as stock markers for fish. Fish. Res., 97: 1-2.

MacKenzie, K. - 2002. Parasites as biological tags in population studies of marine organisms: an update. Parasitol., 124: 153-163.

MacKenzie, K. - 2004. Parasites as biological tags for marine fish populations. Biologist, 51: 86-90.

MacKenzie, K. and P. Abaunza. - 1998. Parasites as biological tags for stock discrimination of marine fish: a guide to procedures and methods. Fish. Res., 38: 45-46.

MacKenzie, K. and P. Abaunza. - 2005. Parasites as biological tags. In: S.X. Cadrin, K.D. Friedland, J.R. Waldman (eds.), Stock identification methods, pp. 211-226. Elsevier, NY.

MacKenzie, K., N. Campbell, S. Mattiucci, P. Ramos, A.L. Pinto and P. Abaunza. - 2008. Parasites as biological tags for stock identification of Atlantic horse mackerel Trachurus trachurus L. Fish. Res. 89: 136-145.

Marcogliese, D.J., E. Albert, P. Gagnon and J.-M. Sévigny. - 2003. Use of parasites in stock identification of the deepwater redfish (Sebastes mentella) in the Northwest Atlantic. Fish. Bull., 101: 183-188.

Marques, J.F., M.J. Santos, J.L. Costa, M.J. Costa and H.N. Cabral. - 2005. Metazoan parasites as biological indicators of population structure of Halobatrachus didactylus on the Portuguese coast. J. Appl. Ichthyol., 21: 220-224.

Marques, J.F., J.M. Santos and H.N. Cabral. - 2009. Zoogeographical patterns of flatfish (Pleuronectiformes) parasites in the Northeast Atlantic and the importance of the Portuguese coast as a transitional area. Sci. Mar., 73(3): 461-471

Martins, M.R. and C. Ferreira. - 1995. Line fishing for black scabbard fish Aphanopus carbo Lowe, 1839 and other deep water species in the eastern mid Atlantic to the north of Madeira. In: A.G. Hopper (ed.), Deep water fisheries of the north Atlantic oceanic slope, pp. 323-325. Kluwer Academic Publishers, Dordrect, The Netherlands.

Mattiucci, S., P. Abaunza, S. Damiano, A. Garcia, M.N. Santos, and G. Nascetti. - 2007. Distribution of Anisakis larvae identified by genetic markers and their use for stock characterization of demersal and pelagic fish from European waters: An update. $J$. Helminthol., 81: 117-127.

Mattiucci, S. and G. Nascetti. - 2008. Advances and trends in the molecular systematics of Anisakid Nematodes, with implications for their evolutionary ecology and host-parasite co-evolutionary processes. Adv. Parasit., 66: 47-148.

McClelland, G. and J. Melendy. - 2007. Use of endoparasitic helminths as tags in delineating stocks of American plaice (Hippoglossoides platessoides) from the southern Gulf of St. Lawrence and Cape Breton Shelf. Fish. Bull., 105: 180-188.

Melendy, J., G. MaClelland and T. Urlbut. - 2005. Use of parasite tags in delineating stocks of white hake (Urophycis tenuis) from the southern Gulf of St. Lawrence and Cape Breton Shelf. Fish. Res., 76: 392-400.

Morales-Nin, B., A. Canha, M. Casas, I. Figueiredo, L.S. Gordo, J.D.M. Gordon, E. Gouveia, C.G. Pineiro, S. Reis and S. Swan. - 2002 Intercalibration of the age readings of the deepwater black scabbard fish Aphanopus carbo (Lowe, 1839). ICES J. Mar. Sc., 59: 352-364.

Morales-Nin, B. and D. Sena-Carvalho. - 1996. Age and growth of the black scabbard fish (Aphanopus carbo) off Madeira. Fish. Res., 25: 239-251.

Mosquera, J., M. Gómez-Gesteira and V. Pérez-Villar. - 2000. Using parasites as biological tags of fish populations: a dynamical model. Bull. Mathemat. Biol., 62: 87-99.

Oliva, M., M.A. González and E. Acuña. - 2004. Metazoan parasite fauna as a biological tag for the habitat of the flounder Hippoglossina macrops from northern Chile, in a depth gradient. $J$. Parasitol., 90: 1374-1377.

Parin, N.V. - 1986. Trichiuridae. In: P.J. Whitehead, M.L. Bauchot, J.C. Hureau, J. Nielsen and E. Tortonese (eds.), Fishes of the North-east Atlantic and the Mediterranean, vol. 2, pp. 976-980. UNESCO, Paris.

Pascoe, P. - 1987. Monogenean parasites of deep-sea fishes from the Rockall Trough (N.E. Atlantic) including a new species. $J$. Mar. Biol. Ass., 67: 603-622.

Pontes, T., S. D’Amelio, G. Costa and L. Paggi. - 2005. Molecular characterization of larval anisakid nematodes from marine fishes of Madeira by a PCR-based approach, with evidence for a new species. J. Parasitol., 91: 1430-1434.

Quinta, R., L. Gomes and A.T. Santos. - 2004. A mitochondrial DNA PCR-RFLP marker for population studies of the black scabbard fish (Aphanopus carbo). ICES J. Mar. Sci., 61: 864-867.

SPSS Inc. - 2007. SPSS Base 16.0 User's Guide. Chicago, IL, USA.

Stephanni, S. and H. Knutsen. - 2007. Phylogeography and demographic history of the deep-sea fish Aphanopus carbo (Lowe, $1839)$ in the NE Atlantic: Vicariance followed by secondary contact or speciation? Mol. Phylogent. Evol., 42: 38-46.

Timi, J.T. - 2007. Parasites as biological tags for stock discrimination in marine fish from South American Atlantic waters. $J$. Helminthol., 81: 107-111.

Wardle, R.A. and J.A. McLeod. - 1952. The zoology of tapeworms. The University of Minnesota Press, Minneapolis, USA.

Whittington, I.D. and L.A. Chisholm. - 2008. Diseases caused by Monogenea. In: J.C. Eiras, H. Segner, T. Wahli and B.G. Kapoor (eds.), Fish Diseases, pp. 683-816. Science Publishers, Enfield, USA.

Williams, T. and B.C. Bedford. - 1974. The use of otoliths for age determination. Proc. Int. Symp. Unwin. Old Woking, UK. pp. 114-123.

Scient ed.: L.S. Gordo.

Received December 12, 2008. Accepted September 27, 2009.

Published online December 22, 2009. 